\title{
Political and legal support of ensuring security and sustainable development of cis member countries
}

\author{
Ekaterina Dolzhenkova ${ }^{1, *}$, Dmitri Mokhorov ${ }^{1}$, and Tatiana Baranova ${ }^{1}$ \\ ${ }^{1}$ Peter the Great St. Petersburg Polytechnic University, St. Petersburg 195251, Russia
}

\begin{abstract}
CIS member countries are interconnected by both historical, cultural and economic components. Russia and China, as two global actors, influence the economic situation and security in the CIS. The purpose of the paper is to identify the dependence of the CIS member countries on Russia and China, as well as to identify dependence of the economic development of the member states on import of armaments. Applying a regional approach, as well as analyzing economic indicators, supplies of weapons and presence of the military industrial complex production and service enterprises, we can define Belarus and Kazakhstan as the states with the largest share of foreign (Russian and Chinese) investments and weapons in their home markets. The Russian Federation stands out in the general context of dominance throughout the CIS. There are also Russian geopolitical interests, which include protection of external borders by ensuring security and stability in the member states bordering third countries. Chinese interests are focused mainly in the border area, namely, Chinese interests in Central Asia. The growing influence of global actors in the region, which is ensured through their investments in industry, military supplies and setting up new production complexes, establishes an ever closer relationship among the nations of the region. Thus, such an influence may lead certain CIS member countries to closer integration with China and Russia in the future, namely, to create bilateral alliances with a higher degree of dependence on global actors in comparison with other CIS member countries.
\end{abstract}

\section{Introduction}

Due to the fact that the CIS member countries choose to participate in certain projects on the basis of their own national interests, it seems to us that each state adheres to the course of sustainable development of the CIS independently and selectively. This suggests that each member state chooses its independent path of development, combining external cooperation with third countries or organizations and the CIS member countries cooperation within the commonwealth. There are two CIS member countries that tend to implement programs or adopt experience of third neighboring states, they are the Republic of Belarus and the Republic of Kazakhstan.

The Republic of Belarus and the Russian Federation are strategic partners. We can assume

\footnotetext{
*Corresponding author: skinx@inbox.lv
} 
a high degree of mutual integration between these two states along with the Russian Federation investment activity in strategic areas of the Belarus economy. In addition to the economic sector, their interconnection also takes place in the sphere of ensuring security both within the countries and in the region as a whole. The location of part of the Russian militaryindustrial complex on the territory of Belarus, as well as conducting various joint RussiaBelarus military exercises clearly illustrate the degree of cooperation in the security sphere.

The Republic of Kazakhstan is considered as a CIS member country with a focus on cooperation with a third country, namely China. There are such promising areas of cooperation as the economy [1], industry, technology, science, etc. Probably, it is appropriate to speak of the growing power of China spreading its geopolitical interests in cooperation with Kazakhstan, which is conditioned by their common borders and the level of economic development of Kazakhstan itself. At the same time, China is interested in maintaining stability at its borders, as well as in securing its international interests in Kazakhstan. Security is also associated with armaments, including the sales market. China is still involved in the export of weapons to Kazakhstan despite the fact that Chinese weapons are represented in a much smaller amount on the Kazakh market than the Russian ones.

The following questions need to be answered to identify the trends of the security development and sustainable development of the CIS. Are China or Russia dominant in the CIS member countries? In which member states do Russia and China play the most dominant roles? In which member states is Russia the most dominant, and in which it is China? What spheres are dominated by China and Russia? Is there any dependence on the military and economic presence of Russia and China in relation to the bordering countries? How do the weapons supply affect security of the CIS countries, and do they have any economic dependence on the supplier countries?

The Republic of Kazakhstan is of strategic importance for both Russia and China not only as a former Soviet Union state territory and as a border area, but also as a transit state. The political system formed after the fall of the Soviet Union, as well as its current position, which influences foreign and domestic policy in Central Asia, and in the CIS in general, is reviewed in the paper by S. Pritchin [2]. V. Larin [3] consideres the People's Republic of China as a global power capable of pursuing an independent foreign policy, based only on its own global interests. The paper also notes that China is developing a separate strategy and behavior for each of its foreign policy directions. Meanwhile, China claims to be a major global financial player, and the role of the People's Bank of China is increasing accordingly [4]. China needs to create favorable conditions for its private companies that could invest outside the Republic, as well as to create a favorable internal investment climate. O. Borokh [5] notes that China's capabilities were not initially accepted in the West, and that one of the reasons for China's dominance in the international arena is directly related to the very concept of its domestic policy, and the leading role of the state in the governance, including the economic sector. The dependence of transport infrastructure and economic development in general, and in China in particular, is considered in the paper by V. Varnavsky [6]. China's dominance in the sphere of weapons and the ways that helped achieve this goal are analyzed in detail in the paper by V. Kashin [7]. Sino-Russian relations intersect in various directions, their further development and possible consequences will affect the Russian Federation in future; due to this, it is important to mention the paper by A. Voskresensky [8]. The work of A. Volodin [9], which examines the dependence of the state policy and the economy is also of interest. With regard to the bilateral relations between Belarus and Russia, it is necessary to highlight the paper by A. Suzdaltsev [10]. To understand the foreign policy of the Republic of Belarus one should pay attention to the paper by F. Basov [11]. 


\section{Methodology}

The purpose of the paper is to determine the relationship between security and sustainable development of the CIS member countries on the part of Russia and China. To achieve this goal, it is necessary to solve the following problems: defining the geopolitical interests of Russia and China in the region; dividing the CIS into the regions of presence of a certain global actor; determining the extent of the global actors' involvement in the internal processes of the CIS member countries. The methodology of this study is based on a regional approach and comparative analysis. Two republics were singled out of all the CIS member countries according to the principle of the closest connection, i.e. the Republic of Kazakhstan and China, and the Republic of Belarus and Russia. The closest connection is defined here as the dependence of these countries on the weapons supplies and foreign investment (by Russia and China), as well as the common borders. Singling out two of these CIS member countries is also considered in the general context of the other member states' dependence on China and Russia. Then the weapons exports and investment amounts by the member states are analyzed.

\section{Results}

Ensuring security in the CIS. The Central Asia region is a part of the U.S. geopolitical interest zone as well. To date, the United States and China have certain tensions, as the Chinese side seeks to take its place as a global power. The military power and its proliferation in zones of influence is also one of the components of the global dominance. It seems appropriate that Central Asia is the region where China has its interests, in particular, its foreign market, border territories, human capital, resources, return on investments, etc. China started spreading its influence in the region through the development of infrastructural, industrial, investment, scientific and other projects. It should also be noted that the Chinese side is the largest exporter of the security systems, technologies and standards. China can be mentioned as one of the most advanced countries for the implementation of the Smart City project. This means that urban infrastructure projects using Smart City technologies will be implemented in this region through the use of the advanced Chinese security technologies.

China's share of the arms market is also increasing annually. According to the SIPRI analytical data [12] (Table 1), China is ranked second in the export of weapons in 2020, and three of its production companies are the top 10 of the Global Arms Industry.

Table 1. Total weapons to the CIS.

\begin{tabular}{|c|c|c|}
\hline \multirow{2}{*}{ CIS Country } & Russian Federation & China \\
\hline & \multicolumn{2}{|c|}{ Total weapons } \\
\hline Armenia & 56 & - \\
\hline Azerbaijan & 900 & - \\
\hline Republic of Belarus & 148 & 10 \\
\hline Kazakhstan & 130 & 8 \\
\hline Kyrgyzstan & 15 & 6 \\
\hline Tajikistan & 10 & 20 \\
\hline Uzbekistan & 22 & 61 \\
\hline
\end{tabular}

China exported the following weapons to the CIS member countries from 2018 to 2019 [13]:

- Republic of Belarus - VN3 armored reconnaissance vehicle - 10 units;

- Republic of Kazakhstan - Y-8F-200WA military transport aircraft [15] - 8 units;

- Kyrgyzstan - Tiger-class auxiliary troops - 6 units;

- Tajikistan - Tiger-class auxiliary troops - 10 units; MRAP armored vehicles - 10 units; 
- Uzbekistan - FD-2000 long-range anti-aircraft missile system [16] - 1 unit; HQ-9 class double-range anti-aircraft missile system - 60 units.

In order to identify the dependence of the CIS member countries armaments on the Russian Federation, it is also necessary to consider the export of Russian weapons in the region over the same period of time:

- Armenia - 9M338/SA-15 class anti-aircraft missile system - 50 units; Tor-M1/SA-15 class mobile anti-aircraft missile system - 2 units; Su-30K class military fighter - 4 units;

- Azerbaijan - BTR-82A class armored personnel carrier - 76 units; 9M123/AT-15 antitank missile - 800 units; 9P157-2 Khrizantema-S class self-propelled anti-tank missile system - 24 units;

- Republic of Belarus - Protivnik-GE multi-mode radar - 7 units; T-72B3 class tank - 25 units; 9M338/SA-15 class anti-aircraft missile system - 100 units; Su-30MK class combat aircraft - 12 units; Tor-M1/SA-15 class mobile anti-aircraft missile system - 4 units;

- Kazakhstan - 9M317/SA-17 Grizzly class anti-aircraft missile system - 100 units; BukM2/SA-17 class anti-aircraft missile system - 1 unit; Mi-35M class combat helicopter - 4 units; Su-30MK class combat aircraft - 20 units; Tigr class auxiliary troops - 5 units;

- Kyrgyzstan - BRDM-2 armored reconnaissance and patrol vehicle - 9 units; Mi8MT/Mi-17 class transport helicopter - 4 units; P-12/Spoon Rest air search radar - 2 units;

- Tajikistan - BRDM-2 armored reconnaissance and patrol vehicle - 9 units; P-12/Spoon Rest air search radar - 1 unit;

- Uzbekistan - Taifun-K-53949 class armored car - 10 units; Mi-35M combat helicopter -12 units.

U.S. military deliveries to the CIS member countries for the period from 2018 to 2019 consisted only of the export of several units of diesel generators to Kazakhstan.

Meanwhile, Airbus, a joint trans-European venture in the aerospace industry, operates in Kazakhstan [17]. Despite the fact that Airbus is also associated with civil aviation, its presence in Kazakhstan may indicate that there is a demand in the market outside Europe, as well as the fact that European manufacturers are interested in the CIS market. For example, many military corporations open their production sites in countries with a substantial domestic demand. The Chinese aviation industry, represented by three companies - AVIC, NORINCO, CETC, is present in the USA, Pakistan, Cambodia, the United Kingdom, Spain and Finland. China does not seek to increase its military production in the CIS countries. But this only shows the peculiarities of the national policies and restrictions for external actors in the CIS market.

Production facilities of the Russian Federation in the missile and space sector are represented in the Republic of Belarus. Russia plans to expand its international presence by creating repair services in importing countries such as Algeria, Egypt, and Kazakhstan. As for the CIS countries, there is information on the plans to establish service centers there as well. In addition, there are Russian weapons manufacturing facilities in Kazakhstan. There is the same trend, when a major weapons importer has its foreign production sites on the territory. In general, Russian weapons manufacturing companies maintain their international presence by establishing foreign service providers. Most of the military production sites in China and Russia are located in their national territories. Moreover, the international presence of Russian and Chinese weapon companies is limited by disagreements in the international arena, including international sanctions.

Speaking of military production, we should keep in mind that this industrial sector today is being modernized by the introduction of modern communication devices, cyber security devices and use of artificial intelligence [18]. These needs can be met both by national capabilities and by foreign technologies. Here we can also mention the significant role of China. 
Ensuring sustainable regional development. Here we can note the possibility of creating new jobs in the countries where production sites are located. The possibility of international cooperation is also reflected in the fact that generally both foreign and local personnel are collaborating in foreign enterprises. The same is true for the scientific exchange, technology exports and imports. The development of foreign production sites also means attracting foreign investment. Thus, investments in the military industry in Kazakhstan and Belarus are mainly provided by the Russian Federation.

As for investments in other sectors of the CIS member country economy, the People's Republic of China is increasing them annually. According to the independent news organization Eurasianet [19], the greatest amount of Chinese investments in Kazakhstan in 2020 was concentrated in the industry (cement and glass production, transport and agriculture). In Uzbekistan, the manufacturing industry and hydrocarbon processing is the main focus for China as well. In Tajikistan, China seeks to invest in mining and agriculture, and in the textiles as in Uzbekistan. In Kyrgyzstan, the mining industry is of interest to China. There is also a large share of private Chinese investment in these states in addition to the government ones.

The Russian Federation, together with the Republic of Armenia, has set up a joint investment fund [20] for the industrial, agricultural and transport projects. According to the Eurasian Development Bank data for 2017 [21], the Russian Federation has investment ties with Uzbekistan and Azerbaijan through LUKOIL Overseas. Russian foreign direct investment is mainly concentrated in Armenia, Uzbekistan, Belarus and Tajikistan. There is also a small share of Russian investments in Azerbaijan, Kyrgyzstan and Kazakhstan. The main spheres of Russian investment activity in the CIS are energy-related activities (subsidiary of Gazprom Transgaz Belarus [22], transport sector, industry and IT-technologies (JLLC Mobile TeleSystems [23]).

\section{Discussion}

The Russian Federation is the undisputed leader in the exports of weapons to the CIS member countries. Thus, the dependence of the commonwealth member states mainly on the Russian military-industrial complex is revealed. Ensuring national security is one of the main objectives of the state national and international policy. In this case, it can be argued that two states, namely Russia and China, ensure the security in the region as a whole. China focused its presence mainly in the bordering countries, i.e. Kazakhstan, Kyrgyzstan, Tajikistan. The Russian Federation has a leading role in the import of weapons to these countries, but provided that China also supplies weapons to these countries, as well as invests in their economies. Their dependence on China's foreign policy is growing both in the sphere of security and in ensuring sustainable development in each country and in the region as a whole.

The Russian Federation maintains its global presence in the CIS member countries mainly by ensuring security in each country individually. The share of Russian arms exports is much larger than that of China. While Chinese arms exports are mainly concentrated in the border states, Russian exports are extended to the entire commonwealth. In addition, the Russian Federation seeks to establish its service centers throughout the CIS. As for other countries, the main external production base of weapons today is located in Kazakhstan and Belarus. This may be a sign that Russia does not want to allow China's dominance in Kazakhstan in ensuring security.

There is also certain dependence in the allocation of investments. China is increasing both its government and private investments in the border states, and Chinese weapons are also exported there. Thus, Chinese investments are made in the countries that import Chinese weapons. Outside this space, China has a more restrained policy in the CIS. This may be 
justified by China's primary interest in security and stability in its border region. Despite the fact that the Russian Federation dominates in the commonwealth and exports weapons to the entire CIS territory, it singles out, firstly, the countries where the weapons production is located (Kazakhstan and Belarus (these countries are also the largest importers of Russian weapons in the CIS)), and secondly, the border areas that also border on third countries (Kazakhstan with China, Belarus with EU countries, Armenia with Turkey and Iran, Azerbaijan with Iran). Thus, the Russian Federation is dominant both in the economies of these countries and in ensuring their security. But it is important to note that in this way Russia ensures security of the entire region. Belarus, where the share of Russian investment and armaments is the highest, should be highlighted additionally. The Russian Federation, as well as China, is interested in the stability of the border states both economically and in the sphere of security.

\section{Conclusion}

The sustainable development of the CIS member countries depends on foreign investment coming from the two global actors. The amount of investments depends on the interest of both Russia and China in stability at their borders, which is ensured by the armaments supply, on the one hand, and by the economic development of the border states through Russian and Chinese investments, on the other hand. The Russian Federation zone of influence is much extensive than that of China. Therefore, the sustainable development and security of the CIS member countries depends on Russian global interests. In view of this peculiarity of the commonwealth, the member states need to strive for integration with the dominant actor in the region. It can be assumed that further development of one of the two global actors will entail an increase in the border states dependence on it, which may lead to closer alliances within the commonwealth.

\section{References}

1. T. Panchenko, Kazahstanu boyatsya nado ne Kitaya. Forbes, https://forbes.kz/process/expertise/ekspertyi_boyatsya_nado_ne_kitaya_a_sobstvennoy _syirevoy_zavisimosti/

2. S. Pritchin, World Economy and International Relations 65(2) (2021)

3. V. Larin, World Economy and International Relations 64(6) (2020)

4. L. Novoselova, World Economy and International Relations 64(6) (2021)

5. O. Borokh, A. Lomanov, World Economy and International Relations 64(6) (2021)

6. V. Varnavskii, World Economy and International Relations 64(1) (2021)

7. V. Kashin, L. Krasheninnikova, A. Piatachkova, World Economy and International Relations 64(7) (2021)

8. A. Voskressenski, World Economy and International Relations 63(10) (2019)

9. A. Volodin, World Economy and International Relations 63(11) (2019)

10. A. Suzdal'tsev, World Economy and International Relations 64(3) (2020)

11. F. Basov, World Economy and International Relations 63(9) (2019)

12. Global arms industry: Sales by the top 25 companies up 8.5 per cent; Big players active in Global South. SIPRI, https://sipri.org/media/press-release/2020/global-arms-industrysales-top-25-companies-85-cent-big-players-active-global-south

13. Trade Registers, https://armstrade.sipri.org/armstrade/page/trade_register.php 
14. VN3, http://www.military-today.com/apc/vn3.htm

15. SMI: Kazahstan 26 sentyabrya poluchit perviy voenno-transportiy samolyot Y-8F200WA,

https://www.kt.kz/rus/society/smi_kazahstan_26_sentjabrja_poluchit_pervij_voennotra nsportnij_samolet_y8f200wa_1153662986.html

16. FD-2000 long range air defense missile system, https://www.armyrecognition.com/china_chinese_army_missile_systems_vehicles/fd2000_long_range_air_defense_missile_system_technical_data_sheet_specifications_pi ctures_video.html

17. L. Beraud-Sudreau, A. Marksteiner, D. Lopes Da Silva, et al, Mapping the international presence of the world's largest arms companies. SIPRI, https://sipri.org/sites/default/files/2020-

12/sipriinsight2012_mapping_the_international_presence_of_the_worlds_largest_arms companies.pdf

18. E. Dolzhenkova, D. Mokhorov, T. Baranova, IOP Conf. Series: Materials Science and Engineering 940 (2020) doi:10.1088/1757-899X/940/1/012015

19. D. Van Der Kley, China diversifies in Central Asia, https://eurasianet.org/chinadiversifies-in-central-asia

20. RDIF to establish Russia-Armenia Investment Fund, https://rdif.ru/Eng_fullNews/2292/

21. A. Kuznetsov, K. Gemuyeva, Y. Kvashnin et al, Monitoring of Mutual Investments in CIS Countries (2017) https://eabr.org/upload/iblock/3fe/EDB-Centre_2017_Report45_MIM-CIS_ENG_2.pdf

22. E. Kuzmina, Integration Math: how much Russia will invest in Belarus, https://eurasia.expert/arifmetika-integratsii-skolko-rossiya-investiruet-v-belarus/

23. Business case studies in Belarus, https://www.belarus.by/en/business/case-studies 